\title{
$\mathrm{Fe}$ 함량변화에 따른 텅스텐카바이드 초경소재의 특성평가 김주훈 ${ }^{1,2} \cdot$ 이정한 ${ }^{1,2} \cdot$ 장준호 $^{1} \cdot$ 오익현 ${ }^{1} \cdot$ 홍성길 ${ }^{2} \cdot$ 박현국 $^{1, *}$ \\ 1한국생산기술연구원 \\ 2전남대학교 신소재공학과
}

\section{Property Evaluation of Tungsten-Carbide Hard Materials as a Function of Fe Contents}

\author{
Ju-Hun Kim ${ }^{1,2}$, Jeong-Han Lee ${ }^{1,2}$, Junho-Jang ${ }^{1}$, Ik-Hyun Oh ${ }^{1}$, Sung-Kil Hong ${ }^{2}$, and Hyun Kuk Park ${ }^{1, *}$ \\ ${ }^{1}$ Korea Institute of Industrial Technology, Gwangju 61012, Republic of Korea \\ ${ }^{2}$ Division of Advanced Materials Engineering, Chonnam National University, Gwangju 61186, Republic of Korea
}

\begin{abstract}
In this study, consolidated WC-Fe compacts as a function of Fe contents were fabricated by a spark plasma sintering method, following the mixed by the ball-milled powder. Fe among the metallic binders was added to WC enhance not only the driving force of sintering process but also suppressing the grain growth. WC-Fe mixed powder samples were fabricated with 5, 10 and $15 \mathrm{wt} . \% \mathrm{Fe}$ contents, and the particle sizes of the mixed powders were determined to be 2.15 to $3.15 \mu \mathrm{m}$, respectively. The WC-Fe mixed powders were processed by spark plasma sintering, at a sintering temperature of $1300^{\circ} \mathrm{C}$. Consequently, the relative densities of the WC-5, 10 and 15 wt.\% Fe sintered-bodies were about 99.2, 99.5 and 100\%, respectively. The grain sizes of the WC-5, 10 and 15 wt.\% Fe sintered-bodies were about $0.92,0.98$ and $1.02 \mu \mathrm{m}$, respectively. The Fe particles penetrated into the WC particles by dissolving and re-precipitation, and the final sintered bodies were completely densified. The mechanical properties of the WC-Fe sintered-bodies exhibited a hardness up to $1934 \mathrm{~kg} \cdot \mathrm{mm}^{2}$ and a fracture toughness above $6.88 \mathrm{MPa} \cdot \mathrm{m}^{1 / 2}$. The microstructure behavior of the WC-Fe sintered-bodies was investigated in terms of mechanical properties to examine their properties for various $\mathrm{Fe}$ contents. In addition, the mechanical and physical properties were compared with the reported values for other sintering-processes, i.e. HFIHS, HIP, etc.
\end{abstract}

(Received January 20, 2020; Accepted June 24, 2020)

Keywords: WC-Fe, spark plasma sintering method, microstructure, grain size, mechanical properties

\begin{abstract}
1. 서 론
텅스텐카바이드(WC)는 자동차 및 선박을 포함한 다양한 산업군의 요소부품으로 사용되며, 특히 난삭재를 가공하는 절삭공구 소재로 널리 사용되고 있다. $\mathrm{WC}$ 는 고융점 및 고경도의 장점을 갖고 있지만 강한 결합에너지 및 높은 용 융온도로 인해 대표적인 난소결성 소재로 분류된다 [1-2]. 이러한 WC의 단점을 보완하기 위해 비교적 용융온도가 낮고 $\mathrm{WC}$ 에 젖음성이 우수한 다양한 소결조제가 첨가된다. 첨가된 소결조제는 소결온도를 낮추면서 $\mathrm{WC}$ 결정립 간에
\end{abstract}

- 김주훈: 석사과정, 이정한: 박사과정, 장준호·박현국·오익현: 연구원, 홍성길: 교수 *Corresponding Author: Hyun-Kuk Park

[Tel: +82-62-600-6270, E-mail: hk-park@kitech.re.kr]

Copyright (c) The Korean Institute of Metals and Materials
준 액상으로 분포하여 소결능을 향상시킨다 [2].

소결조제로는 코발트 $(\mathrm{Co})$, 철 $(\mathrm{Fe})$ 및 니켈 $(\mathrm{Ni})$ 등과 같은 소재가 첨가되며, 이 중 $\mathrm{Co}$ 는 젖음성 $(\mathrm{Co}: 22 \mathrm{wt} \%)$ 이 우 수하고 $\mathrm{WC}$ 의 취약한 파괴인성을 향상시켜 대표적인 소결 조제로 사용되고 있다 [3-4]. $\mathrm{Co}$ 는 초기 $417^{\circ} \mathrm{C}$ 까지 $\mathrm{HCP}$ 결정구조를 유지하다 그 이상의 온도 및 냉각 후 에는 $\mathrm{FCC}$ 결정구조를 유지하게 된다 [5]. 이렇게 유지된 FCC$\mathrm{Co}$ 의 경우 $\mathrm{HCP}-\mathrm{WC}(0001)$ 면과의 유일한 정합계면을 형성 하게 되고 [6-8] 균열 발생시 정합상 계면에 도달하였을 때 균열은 결정립계 $(\mathrm{WC} / \mathrm{Co})$ 보다는 $\mathrm{WC}$ 와 정합 계면을 이루고 상대적으로 슬립이 많이 발생되는 $\mathrm{Co}$ 의 결정립내 로 전파하려는 경향을 갖게 된다. 이로 인해 비교적 연성 인 $\mathrm{Co}$ 는 균열의 선단을 흡수하여 전파를 방해하고 이에 따라 파괴인성이 향상된다고 보고되었다 [6-8]. 
그러나 $\mathrm{Co}$ 의 원료단가는 타 소결조제 보다 비싸고 희토 류, 및 리튬 등과 같이 향후 수출규제 항목에 포함될 것이 라는 보고가 있어 원료단가를 낮추고 기계적 특성을 향상 시킬 수 있는 새로운 소결조제에 대한 연구 필요성이 대두 되고 있다 [9-10]. $\mathrm{Fe}$ 는 $\mathrm{Co}$ 보다 약 $30 \%$ 낮은 젖음성 (Fe: $7 \mathrm{wt} \%)$ 을 가지지만 기존의 소결조제 보다 원료단가 를 낮출 수 있으며, 결정립 성장 또한 제어할 수 있다고 보고되고 있다 [3]. 특히 경도 및 파괴인성은 초경소재의 가장 중요한 기계적 특성으로 간주되며, Hall-petch 식에 의하면 미세 결정립을 형성할수록 경도와 내마모성 등의 기계적 성질이 크게 향상된다고 알려져있다 [11].

따라서, 본 연구에서는 $\mathrm{Fe}$ 함량변화에 따라 제조된 $\mathrm{WC}$ 계 혼합분말을 방전플라즈마 소결법을 이용하여 고밀도의 소결체를 제조하였다. 제조된 소결체의 결정립 분석과 경 도 및 파괴인성을 평가하였으며, 기존 연구된 $\mathrm{WC}$ 계 초경 합금과의 특성을 비교하였다.

\section{2. 실험방법}

초기 원료 분말로는 WC 분말 (Taegutec Ltd., 1.0 $1.6 \mu \mathrm{m}$, 순도 99.95\%)과 $\mathrm{Fe}$ 분말(Yuelong metal Powder Co. Ltd, $5 \sim 10 \mu \mathrm{m}$, 순도 $99.5 \%$ )을 사용하였다. 그림 1은 초기 분말의 형상을 관찰하기 위해 전계방사형 주사전자 현미경 (FE-SEM)을 이용하여 미세조직을 분석한 결과이 다. 그림 1 에서와 같이 $\mathrm{WC}$ 는 불규칙한 형상을 띄고 있으 며, $\mathrm{Fe}$ 분말의 경우 구 형태의 미세조직을 확인하였다. $\mathrm{WC}$ 분말에 5,10 및 $15 \mathrm{wt} \%$ 의 $\mathrm{Fe}$ 를 첨가하였고 수평 볼밀링 공정으로 분말을 혼합하였다. 볼은 지르코니아 볼 을 사용하였으며, 볼과 분말의 비율은 $2: 1$ 의 무게비로 혼 합하였다. 밀도차가 큰 $\mathrm{WC}$ 와 $\mathrm{Fe}$ 의 균일 혼합을 위해 $\mathrm{PCA}$ (에탄올)을 첨가한 습식 볼밀링 공정을 진행하였고, 공정조건은 $300 \mathrm{RPM}$ 의 속도로 24 시간 공정 후 진공오븐 을 이용하여 24시간동안 건조하였다.

제조된 분말을 각각 흑연다이 (외경: $30 \mathrm{~mm}$, 내경: 10 $\mathrm{mm}$, 높이: $40 \mathrm{mmT}$ )에 충진 후 흑연 펀치로 상하부를 밀봉하였다. 흑연 다이를 소결 장치에 장착시킨 후 약 6 $\mathrm{Pa}$ 의 진공상태에서 $60 \mathrm{MPa}$ 의 소결압력을 인가하였다. 소 결온도는 열화상 카메라(pyrometer)를 이용하여 흑연 다이 의 중앙 표면을 관찰하였다. 1 차 실험으로 $\mathrm{WC}-15 \mathrm{wt} \%$ $\mathrm{Fe}$ 의 혼합분말을 이용하여 승온속도 $70^{\circ} \mathrm{C} / \mathrm{min}$ 로 약 18 분 동안 $1300{ }^{\circ} \mathrm{C}$ 까지 소결을 진행하였고 상대밀도 약 $92 \%$ 의 소결체를 제조하였다. 2 차 실험에서는 1 차 실험 데이터를 참고하여 급격한 수축변위가 일어난 $1100{ }^{\circ} \mathrm{C}$ 부근에서 5 분

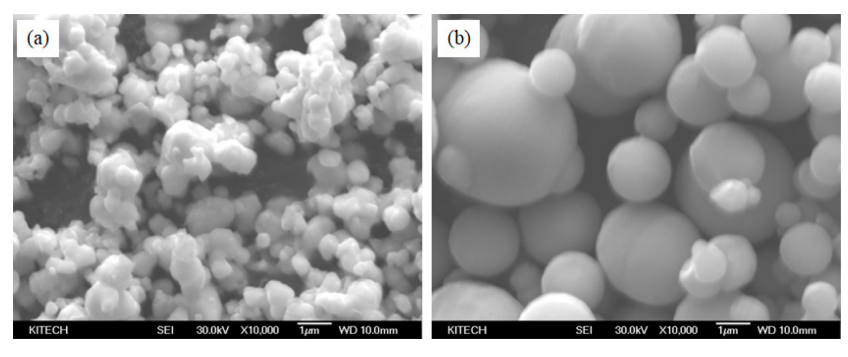

Fig. 1. Micromorphology of WC and Fe raw powders: (a) WC and (b) Fe.

유지시켰다. 이 후 목적온도인 $1300{ }^{\circ} \mathrm{C}$ 까지 도달한 후 5 분 유지 시키고 소결을 종료하였다. 소결 종료 후 냉각시 $600{ }^{\circ} \mathrm{C}$ 에서 압력을 제거하였다.

소결이 완료된 소결체의 밀도는 아르키메데스법을 이용 하여 측정하였다. 소결체의 표면 관찰을 위해 무라카미 부 식액 $\left(5 \mathrm{~g} \mathrm{Fe}_{3}(\mathrm{CN})_{6}, 5 \mathrm{~g} \mathrm{NaOH}\right.$ 및 $50 \mathrm{ml}$ 의 증류수)으로 약 1분간 표면을 부식시켰다 [12]. FE-SEM을 이용하여 소결체의 미세구조를 분석하였으며, X-선 회절분석기를 통 해 상분석을 진행하였다. 소결체의 결정립 크기는 전자 후 방 산란 회절분석기 (Electron backscatter diffraction, $\mathrm{EBSD}$ )를 통해 분석하였다. 시료 전처리를 위해 제조한 소 결체는 총 3 회에 걸쳐 $\left(1\right.$ 차 $10^{\circ} \mathrm{C}, 8 \mathrm{Kv}, 10$ 분, 2 차 $8^{\circ} \mathrm{C}, 6 \mathrm{Kv}, 10$ 분, 3 차 $6{ }^{\circ} \mathrm{C}, 4 \mathrm{Kv}, 10$ 분) 이온밀링을 진 행하였다. 결정립 크기 분석은 결정립들이 차지하고 있는 분률 (Area Fraction)과 각 결정립들의 Average Area 값 을 도출하여 제조된 소결체의 결정립 크기를 분석하였다. 비커스 경도계를 이용하여 $20 \mathrm{~kg} \cdot \mathrm{f}$ 하중으로 15 초간 유지 하였으며, 발생된 시편의 압흔 및 균열의 길이를 측정하여 경도 및 파괴인성을 평가하였다.

\section{3. 실험결과 및 고찰}

\section{1. 방전플라즈마 소결법을 이용한 WC-Fe의 소결특 성 분석}

그림 2-(a) 1차 실험과 (b) 2차 실험에서의 소결시간에 따른 소결온도 및 수축길이 변화를 그래프로 나타내었다. 그림 2-(a)의 경우 약 $950^{\circ} \mathrm{C}$ 부근에서 수축이 시작되었고 $1100{ }^{\circ} \mathrm{C}$ 온도부근에서 급격한 수축을 관찰하였으며, 앞서 설명한 내용과 같이 약 $92 \%$ 의 상대밀도를 가지는 것으로 분석되었다. 그림 2-(b)의 경우 펄스전류를 인가하고 약 100 초 이후부터 $\mathrm{Fe}$ 함량변화에 따라 다소 상이한 수축 거 동 변위를 나타내었지만 $1100{ }^{\circ} \mathrm{C}$ 등온하는 소결과정으로 인해 $\mathrm{Fe}$ 의 함량에 따라 약 2 2.5 mm까지 수축하는 것으 

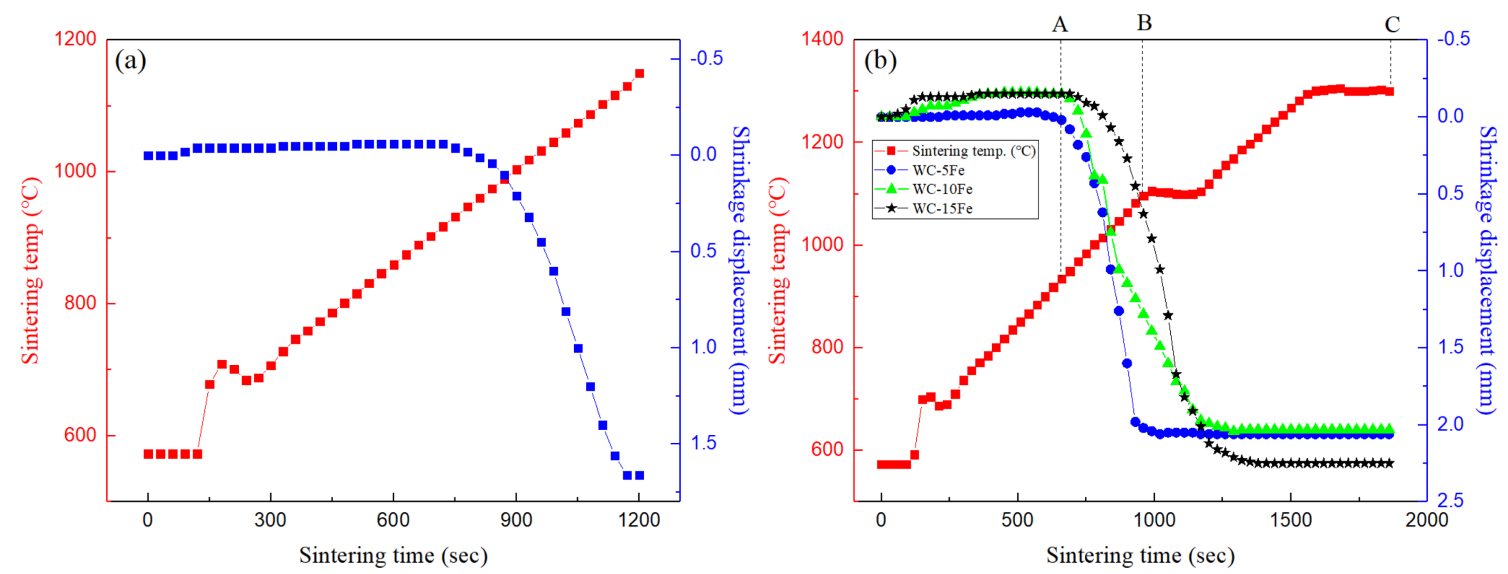

Fig. 2. Schematic representation of the temperature and shrinkage displacement profile during SPS process: (a) direct process and (b) holding process.

로 확인되었다. 초기 팽창 원인으로는 $\mathrm{WC}\left(5.5 \times 10^{-6} / \mathrm{K}\right)$, $\mathrm{Fe}\left(11.8 \times 10^{-6} / \mathrm{K}\right)$ 및 흑연몰드/펀치 $\left(1.7 \times 10^{-6} / \mathrm{K}\right)$ 에 직류펄 스전류를 인가함에 따라 발생된 열에 의한 각 소재의 열팽 창계수 차이 때문으로 판단된다. 그림 2-(b)의 수축길이 그 래프에 나타낸 것과 같이 세 가지 소결체 모두 $\mathrm{A}$ 지점 (약 $\left.900.6{ }^{\circ} \mathrm{C}\right)$ 에서 수축이 시작되었고 $\mathrm{B}$ 지점 $\left(\right.$ 약 $1100{ }^{\circ} \mathrm{C}$ 부근) 에서 공통적으로 급격한 수축이 진행되었다. 최종 소결체의 상대밀도는 $\mathrm{Fe}$ 의 함량이 증가함에 따라 상대밀도 또한 약 99.2, 99.5 및 $100 \%$ 로 증가하는 경향을 나타내었다.

치밀화에 대한 구동력은 소결압력이나 충격에너지가 커 짐에 따라 밀도가 증가한 후 일정한 포화치에 도달한다. 물질의 소성변형은 항복응력 이상에서 발생되므로 치밀한 생성물을 얻기 위해서는 일정 임계치 이상의 압력을 인 가해야 되며, 소결에 대한 전체 구동력 $\mathrm{F}_{\mathrm{D}}$ 는 다음 식과 같다.

$$
\mathrm{F}_{\mathrm{D}}=\gamma+(\mathrm{Par} / \pi)
$$

여기서 $r$ 는 계면에너지, $\mathrm{Pa}$ 는 인가압력, $\mathrm{r}$ 은 결정립의 반 경을 나타낸다.

본 연구와 비교시 소결한 소재는 다르지만 소결 압력이 상대밀도에 미치는 영향을 연구한 전북대학교 손교수 연구 팀에 따르면 $1000{ }^{\circ} \mathrm{C}$ 에서 소결하는 도중에 상대압력을 60 $\mathrm{MPa}$ 에서 $100 \mathrm{MPa}$ 로 증가함에 따라 상대밀도는 현저히 증 가하였다 [13]. 본 연구에서는 소결압력을 $60 \mathrm{MPa}$ 로 고정 하였지만 소성변형이 가능한 임계치 이상의 소결압력을 적 용하고 또한 $70^{\circ} \mathrm{C} / \mathrm{min}$ 의 빠른 승온속도를 적용함에 따라 원자의 확산을 가속화 하여 [4] 기존 타 소결법 대비 낮은 온도에서 고밀도의 소결체를 제조한 것으로 판단된다.

그림 3은 $\mathrm{Fe}$ 함량 변화에 따라 제조된 혼합분말 및 소
결체의 XRD 상분석 결과이다. 혼합분말 및 소결체 모두 $\mathrm{WC}$ 및 $\mathrm{Fe}$ 외 제 2상은 분석되지 않았고 $6 \mathrm{~Pa}$ 의 고진공 상태에서 짧은 소결시간으로 인해 불순물 혼입방지가 가능 하였기 때문으로 판단된다. 하지만 그림 3-(b)의 경우 약 $27^{\circ}$ 부근에서 Graphite 상이 관찰되었다. Graphite 상은 $\mathrm{WC}$ 내부 탄소활성의 변화로 Graphite 상으로 석출되거나 소결조제 내부로 확산되는 과정에서 3원계 탄화물 $\left(\mathrm{M}_{6} \mathrm{C}\right.$ 및 $\mathrm{M}_{12} \mathrm{C}$ 형태; $\mathrm{M}$ : Metallic binder)을 형성할 수 있다. 또한, 소결 시 냉각속도의 차이에 의해서 이러한 제 2 상들 의 발생 거동이 결정될 수 있다고 보고되고 있다 [14]. 따 라서, 그림 3-(b)에서 Graphite 상이 검출 된 원인으로는 $\mathrm{WC}$ 의 치밀화 과정에서 소결조제 내부로의 상호확산 과정 에서의 $\mathrm{W}$ 와 $\mathrm{C}$ 고유의 활성도 차이에 의하여 Graphite 단 일 상이 잔류된 것으로 판단되며, 종래의 소결법에 비해 빠른 냉각속도에 따라 3 원계의 복탄화물을 형성하지 않고 Graphite 상으로 석출 되는 것으로 확인된다.

그림 4는 WC-Fe 소결체의 함량별 최종 소결체에서의 미세구조 사진을 image_J 소프트웨어를 이용하여 $\mathrm{Fe}$ (red) 를 나타내었다. 그림 4 에서 전체적으로 함량이 증가함에 따라 $\mathrm{WC}$ 와 $\mathrm{Fe}$ 가 혼재된 미세조직을 확인 할 수 있었다. 특히 그림 4-(b), 및 (c)의 경우 $\mathrm{WC}$ 와의 확산이 활발히 진행되어 $\mathrm{Fe}$ 의 준 액상과 $\mathrm{WC}$ 의 고체입자들이 동시 확산 되어 있음을 확인할 수 있었다. WC보다 소결온도가 낮은 $\mathrm{Fe}$ 의 준 액상이 형성되면 모세관력이 입자들을 재배열한다. 그리고 용해-재석출이 입자형상변형과 치밀화를 일어나게 한다. 최종적으로는 접촉한 입자 사이에 안정화된 목이 형 성되고 최종 치밀화는 고상 골격 (solid skeleton)의 소결 에 의존한다. 고용도를 가진 많은 양의 준 액상은 고상과 의 확산으로 치밀화를 돕는다 [15]. $\mathrm{Fe}$ 의 함량이 증가함에 

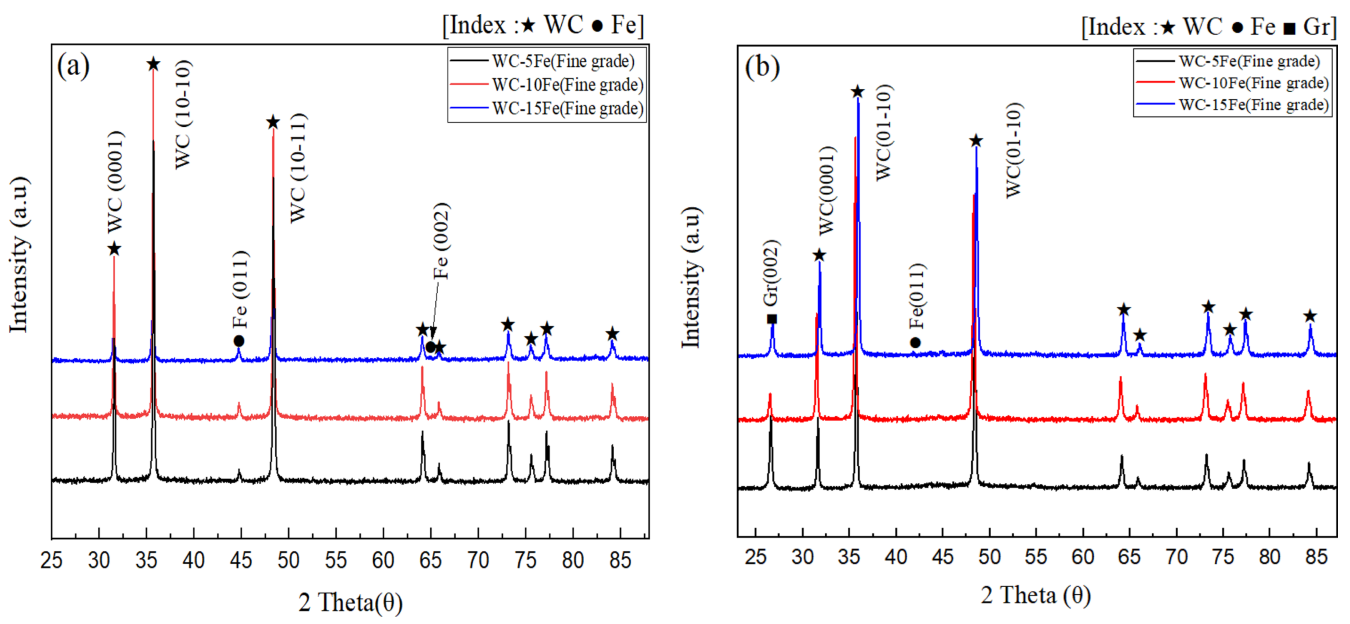

Fig. 3. XRD patterns of WC-Fe materials: (a) mixed-powders and (b) sintered-bodies.
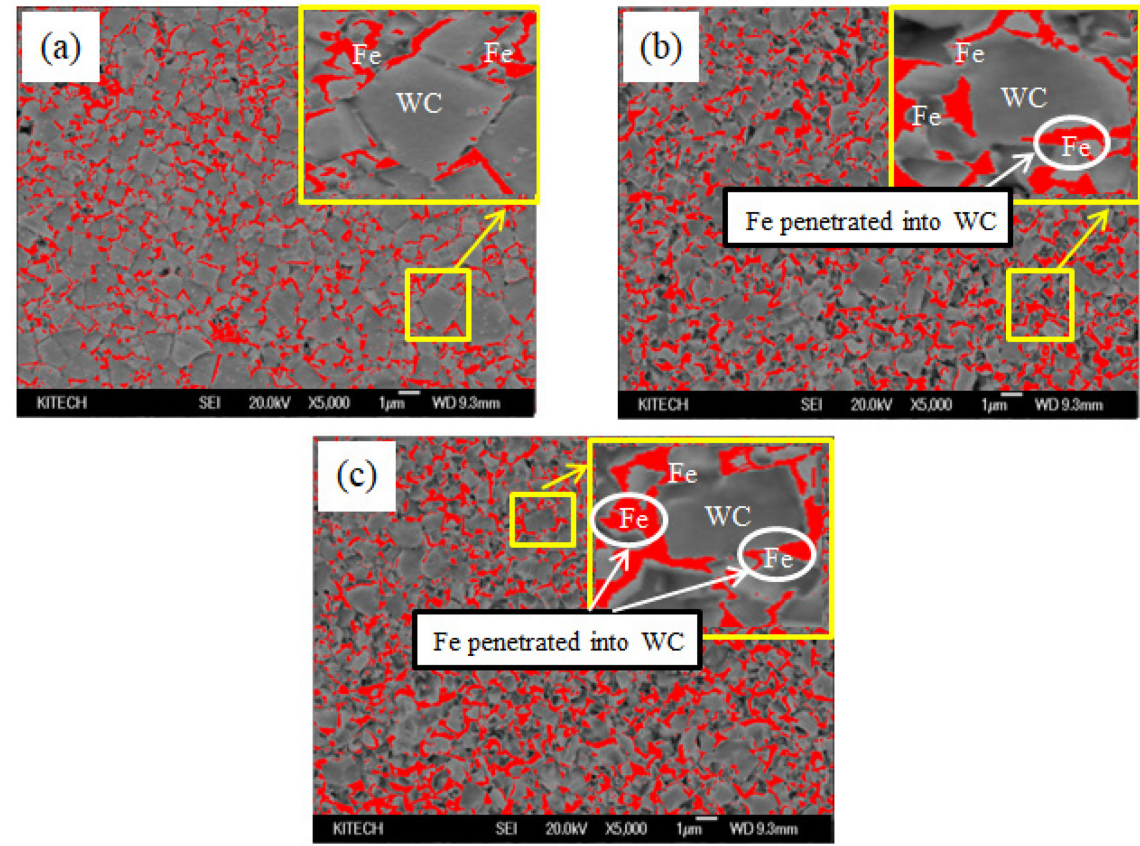

Fig. 4. FE-SEM images of WC-Fe sintered-bodies: (a) WC-5 wt.\% Fe, (b) WC-10 wt.\% Fe and (c) WC-15 wt.\% Fe.

따라 $\mathrm{WC}$ 와 $\mathrm{Fe}$ 의 혼재된 상의 분률이 증가하는 경향을 띄 었고 이에 최종 치밀화에 영향을 끼쳤다고 판단된다.

\subsection{WC 결정립 성장 제어}

그림 5 는 원료분말과 혼합분말의 입도분석을 나타내었다. 원료분말의 평균 입도 분석 결과 원료분말인 $\mathrm{WC}$ 및 $\mathrm{Fe}$ 의 평균입도는 그림 5-(a) 및 (b)와 같이 약 1.38 및 $6.11 \mu \mathrm{m}$ 로 확인되었다. 혼합분말의 입도 분석 결과 $\mathrm{Fe}$ 함 량이 증가함에 따라 약 $2.15 \mu \mathrm{m}$ 에서 최대 $3.47 \mu \mathrm{m}$ 까지 증가한 것으로 그림 5-(c e)와 같이 분석되었다. 혼합 분
말의 평균 입도가 증가한 원인으로는 밀링 에너지가 낮은 수평 볼밀링 공정을 이용함으로 밀링시 발생되는 합금화 및 미세화는 발견되지 않았고 지르코니아 볼을 사용함에 따라 분말이 파쇄되는 에너지에 도달하지 않았다. 이에 볼 밀링 시 단순 균일 혼합과정만을 거침에 따라 $\mathrm{WC}$ 보다 입 도가 큰 $\mathrm{Fe}$ 의 함량이 증가함에 따라 평균 입도가 증가하 는 것으로 분석되었다.

EBSD 분석을 통해 $\mathrm{Fe}$ 함량변화에 따라 제조된 WC-Fe 소결체의 결정립 크기를 분석하였고 그림 6 에 나타내었다. 5,10 및 $15 \mathrm{wt} \% \mathrm{Fe}$ 가 첨가된 $\mathrm{WC}$ 의 평균 결정립 크기 

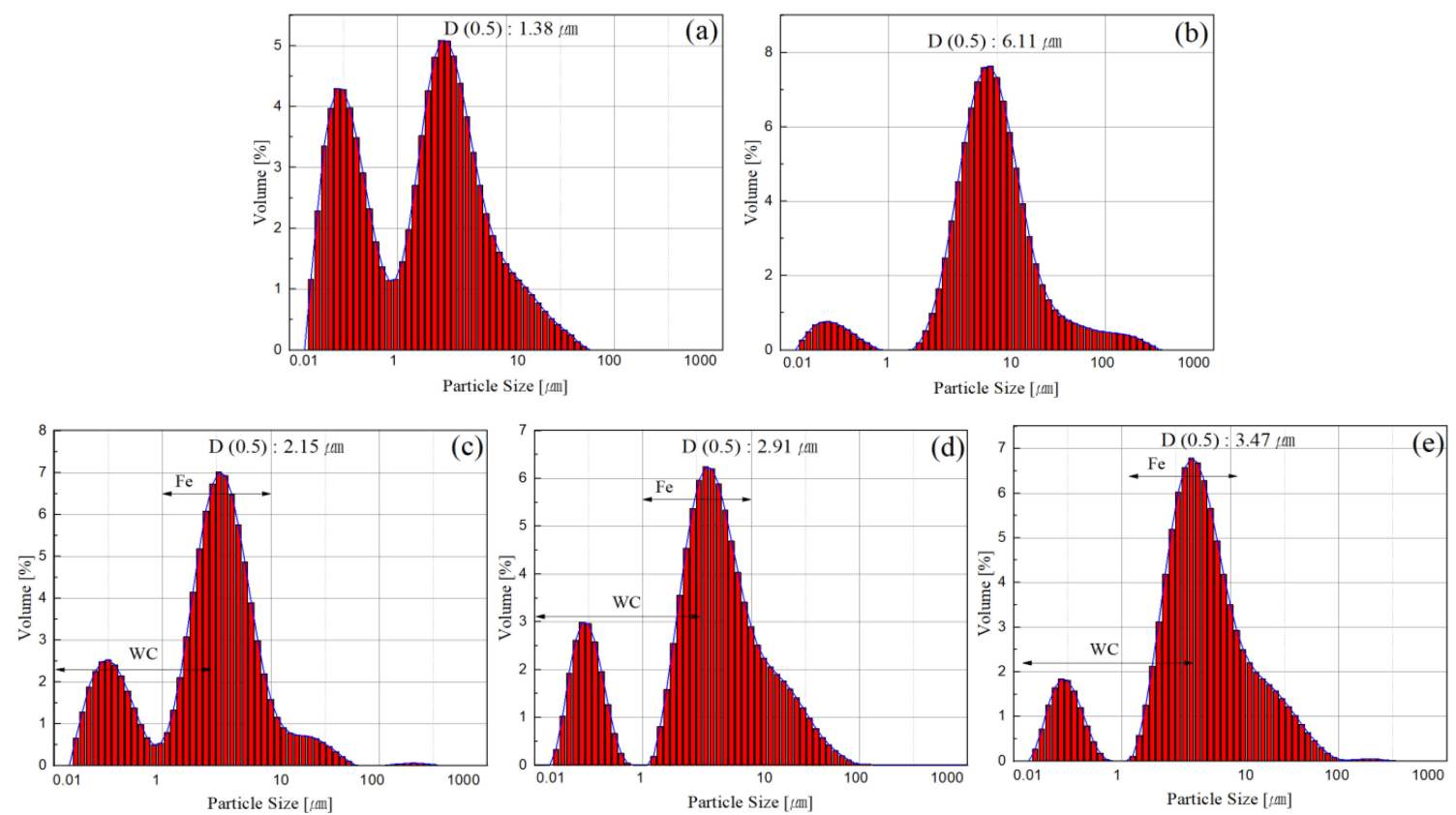

Fig. 5. Particle size analysis of the raw and WC-Fe mixed powders: (a) WC, (b) Fe, (c) WC-5wt.\% Fe and (d) WC-10wt.\% Fe, (e) WC15 wt.\% $\mathrm{Fe}$

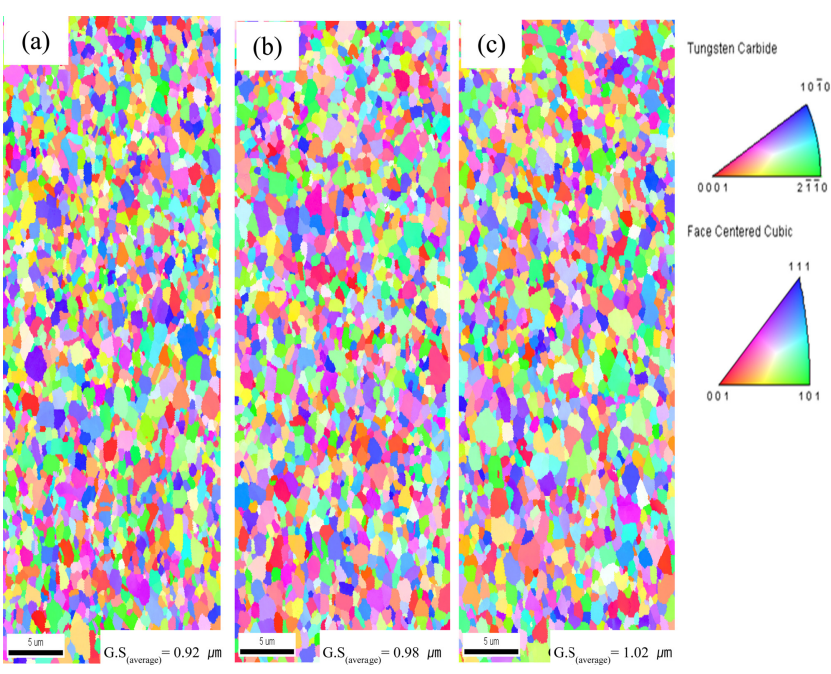

Fig. 6. EBSD analysis of WC-Fe sintered-bodies: (a) WC-5 wt.\% $\mathrm{Fe}$ (b) WC-10 wt.\% Fe and (c) WC-15 wt.\% Fe.

는 약 $0.92,0.98$ 및 $1.02 \mu \mathrm{m}$ 로 분석되었다. $\mathrm{Fe}$ 함량이 증가함에 따라 $\mathrm{WC}$ 결정립 성장을 제어할 것으로 예상하 였지만 $\mathrm{EBSD}$ 분석결과 결정립 크기는 거의 유사한 것으 로 분석되었다.

\section{3. 제조한 WC-Fe 소결체의 기계적 특성 평가 및} 기존 연구와의 비교

그림 7은 $\mathrm{WC}-\mathrm{Fe}$ 소결체들의 기계적 특성 결과를 나타

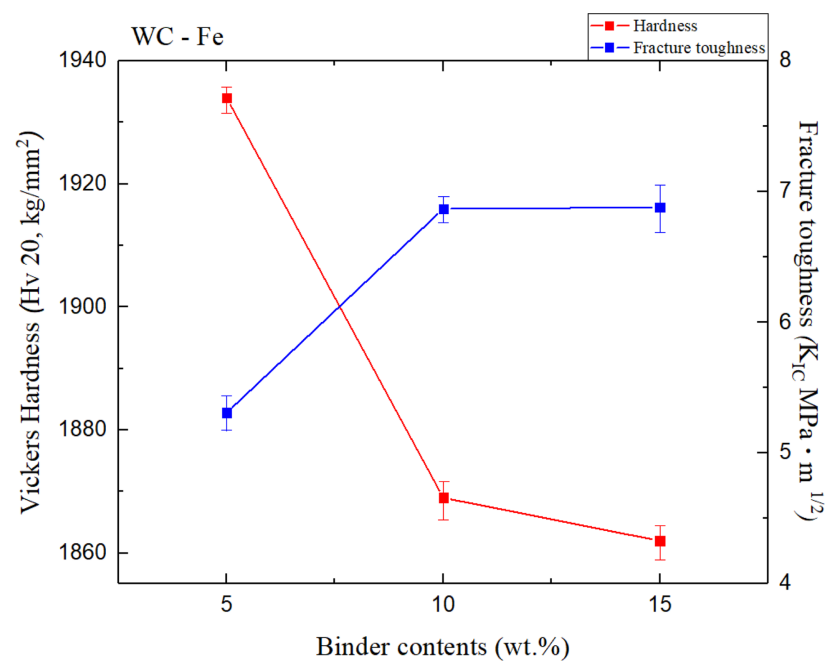

Fig. 7. Variation of mechanical properties of WC-5, 10, 15 wt.\% Fe sintered- bodies.

내었다. 표면 연마된 WC-Fe계 소결체의 경도는 비커스 경 도계로 측정하였으며, 압흔 및 전파된 균열 길이를 Antis 식을 통해 파괴인성을 측정하였다 [16].

$$
\mathrm{K}_{\mathrm{IC}}=0.016(\mathrm{E} / \mathrm{H})^{1 / 2} \mathrm{P} / \mathrm{C}^{3 / 2}
$$

여기서 $\mathrm{E}$ 는 탄성계수, $\mathrm{H}$ 는 경도, $\mathrm{P}$ 는 하중이며, $\mathrm{C}$ 는 크 랙의 길이를 나타낸다. WC-5, 10 및 $15 \mathrm{wt} \% \mathrm{Fe}$ 탄성계 수는 각각 $671.7,647.5$ 및 $623.2 \mathrm{GPa}$ 이며, 7회 측정된 

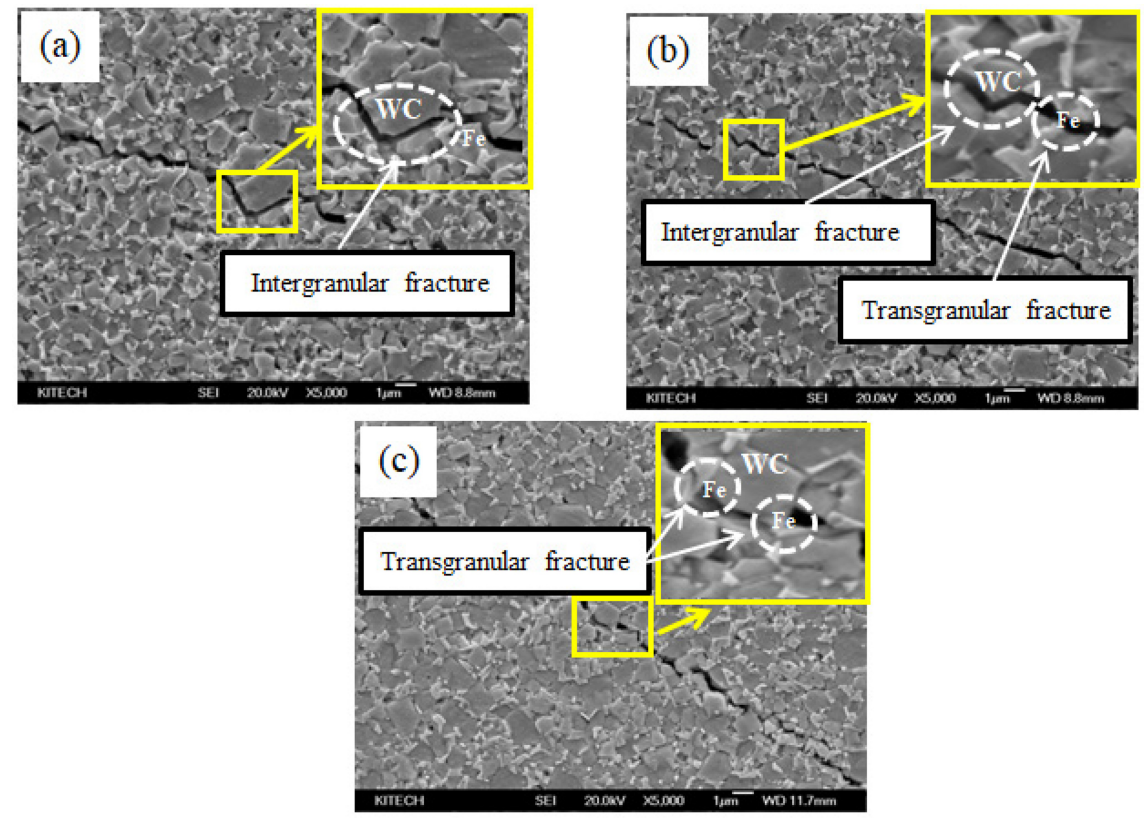

Fig. 8. FE-SEM images of crack propagation on sintered-bodies: (a) WC-5 wt.\% Fe, (b) WC-10 wt.\% Fe and (c) WC-15 wt.\% Fe.

Table 1. Comparison of mechanical/physical properties of WC-Fe sintered in this study with other literatures.

\begin{tabular}{ccccccc}
\hline Reference & Sintered process & $\begin{array}{c}\text { Binder content } \\
(\mathrm{wt} . \%)\end{array}$ & $\begin{array}{c}\text { Relative density } \\
(\%)\end{array}$ & $\begin{array}{c}\text { Grain size } \\
(\mathrm{mm})\end{array}$ & $\mathrm{Hv}\left(\mathrm{kg} / \mathrm{mm}^{2}\right)$ & $\mathrm{K}_{1 \mathrm{C}}\left(\mathrm{MPa} \cdot \mathrm{m}^{1 / 2}\right)$ \\
\hline$[20]$ & HFIHS & WC - 10Co & 98.2 & 4.5 & 1776 & 10.6 \\
{$[20]$} & HFIHS & WC - 10Fe & 99.7 & 4.5 & 1814 & 10.4 \\
{$[21]$} & HIP & WC - 10Co & 99.5 & 1.9 & 1333 & 13.5 \\
{$[21]$} & HIP & WC-9.6Ni-Co & 99.5 & 1.8 & 1180 & 12.5 \\
This work & SPS & WC - 5 Fe & 99.2 & 0.92 & 1934 & 5.31 \\
& SPS & WC - 10 Fe & 99.5 & 0.98 & 1869 & 6.87 \\
& SPS & WC - 15 Fe & 99.9 & 1.02 & 1862 & 6.88 \\
\hline
\end{tabular}

값의 최대/최소 값을 제외한 평균 경도 및 파괴인성 값은 $\mathrm{WC}-5 \mathrm{wt} . \% \mathrm{Fe}$ 가 약 $1934 \mathrm{~kg} \cdot \mathrm{mm}^{2}$ 값으로 최대 경도를 나타내었고 $\mathrm{WC}-15 \mathrm{wt} \% \mathrm{Fe}$ 가 약 $6.88 \mathrm{MPa} \cdot \mathrm{m}^{1 / 2}$ 로 최대 파괴인성을 가지는 것으로 분석되었다. 소결조제의 함량이 적을수록 높은 경도값을 가졌지만 소결조제 함량이 증가함 에 따라 파괴인성 값이 증가하는 경향을 보였으며, 표 1에 기계적 특성 값을 나타내었다.

파괴인성 향상 거동을 분석하기 위하여 비커스 경도계를 이용해 압흔을 형성한 후, 발생된 균열의 거동을 미세조직 으로 분석하였다. 균열은 $\mathrm{WC}$ 입자와 수직으로 만나는 경 우 결정립내 파괴, 벽개면을 따라 균열이 진행되는 경우는 결정립계 파괴가 이뤄진다 [17]. 그림 8-(a)와 같이 $\mathrm{Fe}$ 의 함량이 낮은 소결체의 경우 $\mathrm{WC}$ 입자의 벽개면을 따라 균 열이 진행되는 결정립계 파괴 경향이 다소 많았지만, $\mathrm{Fe}$ 의
함량이 증가함에 따라 그림 8-(b), 및 (c)와 같이 WC 결정 립 내로 확산된 $\mathrm{Fe}$ 가 균열의 선단을 흡수하여 무뎌지게 하 고 이에 따라 파괴인성이 증가한 것으로 판단된다 [17-19].

표 1 에서와 같이 방전플라즈마 방법을 이용하여 제조된 $\mathrm{WC}-5,10$ 및 $15 \mathrm{wt} \% \mathrm{Fe}$ 소결체의 상대밀도, 결정립 크 기, 경도 및 파괴인성 값을 기존의 소결법으로 제조된 WC계 소재 연구결과와 비교분석 하였다 [20,21]. 선행연 구와 비교시 상대밀도, 경도 및 결정립 크기는 우수한 물 성을 가졌다. 특히, 동일한 함량을 첨가한 소결조제 특성 비교시 본 연구에서 제조한 $\mathrm{WC}-10 \mathrm{wt} \% \mathrm{Fe}$ 가 가장 범용 적으로 사용되는 $\mathrm{WC}-10 \mathrm{wt} \%$ Co [21]에 비해 약 $18 \%$ 정도 향상된 경도 값을 가진 소결체를 얻을 수 있었지만 파괴인성 값의 경우 약간 낮은 값이 측정되었다. 


\section{4. 결 론}

$\mathrm{WC}$ 와 $\mathrm{Fe}$ 분말을 원료로 사용하여 수평 볼밀링 공정을 통해 균일 혼합 공정을 수행하였다. 혼합된 합금 분말을 방전플라즈마 소결법을 이용하여 짧은 시간 내에 치밀한 $\mathrm{WC}-5,10$ 및 $15 \mathrm{wt} \% \mathrm{Fe}$ 조성의 초경합금을 제조하였고, 다음과 같은 결론을 얻었다.

1. $\mathrm{WC}$ 및 $\mathrm{Fe}$ 원료분말을 수평 볼밀링 공정을 이용하여 균일 혼합과정을 거쳤고 $\mathrm{WC}-5,10$ 및 $15 \mathrm{wt} \% \mathrm{Fe}$ 혼합 된 분말의 입도는 각각 약 $2.15,2.91$, 및 $3.47 \mu \mathrm{m}$ 크기의 혼합분말을 제조하였다.

2. WC-Fe 혼합 분말을 초기물질로 하여 $1300{ }^{\circ} \mathrm{C}$ 의 소 결온도에서 $60 \mathrm{MPa}$ 의 압력과 $70^{\circ} \mathrm{C} / \mathrm{min}$ 의 승온속도로 소 결을 진행하였으며, 등온구간은 1100 및 $1300{ }^{\circ} \mathrm{C}$ 에서 5 분 간 유지하였다. 최종적으로 $99.2,99.5$ 및 $100 \%$ 의 고밀도 를 갖는 WC-5, 10 및 $15 \mathrm{wt} \% \mathrm{Fe}$ 소결체를 약 30 분 이 내로 단시간에 제조할 수 있었다.

제조된 $\mathrm{WC}-\mathrm{Fe}$ 소결체의 $\mathrm{WC}$ 결정립 크기는 초기 원료 분말 $(1.0 \sim 1.5 \mu \mathrm{m})$ 과 비교시 결정립 성장이 거의 없는 약 $1.02 \mu \mathrm{m}$ 이하 크기를 가지는 것으로 분석되었으며, 이는 첨가된 $\mathrm{Fe}$ 가 $\mathrm{WC}$ 결정립 계면에 분포하여 $\mathrm{WC}$ 의 결정립 성장을 제어한 것으로 판단된다.

또한 결정립 성장이 제어된 고밀도의 WC-Fe 소결체는 기존 선행 연구와의 특성과 비교시 우수한 기계적 특성을 가지는 것으로 분석되었으며, 경도의 경우 $\mathrm{WC}-5 \mathrm{wt} \% \mathrm{Fe}$ 가 약 $1934 \mathrm{~kg} \cdot \mathrm{mm}^{2}$, 파괴인성의 경우 $\mathrm{WC}-15 \mathrm{wt} \% \mathrm{Fe}$ 가 약 $6.88 \mathrm{MPa} \cdot \mathrm{m}^{1 / 2}$ 으로 우수한 특성을 가지는 것으로 분석 되었다.

\section{감사의 글}

본 논문은 한국생산기술연구원 기관주요사업 "생산기술 산업선도 핵심기술 개발사업 (1/4) - 현장설비 부착형 극저 온 통합가공시스템 개발사업 (KITECH EO-20-090)"의 지 원으로 수행한 연구입니다.

\section{REFERENCES}

1. J. H. Lee, I. H. Oh, J. H. Jang, S. K. Hong, and H. K. Park, J. Alloys compd. 786, 1 (2019).
2. H.-K. Park, J.-H. Lee, J. H. Jang, and I.-H. Oh, Korean J. Met. Mater. 57, 304 (2019).

3. J. H. Lee, H. K. Park, J. H. Jang, and I. H. Oh, Met. Mat. Int. 25, 268 (2019).

4. H. C. Kim, Ph D. Thesis, pp.15-79, Chonbuk University, Chonbuk (2005).

5. T. Ericsson, Acta Metall., 14, 853 (1966).

6. I. Konyashin, S. Hlawatschek, B. Ries, F. Lachmann, F. Dorn, A. Sologubenko, and T. Weirich, Int. J. Refract. Met. H. 27, 234 (2009).

7. C. Xu, X. Ai, and C. Huang, Int. J. Refract. Met. H. 19, 159 (2001).

8. J. Xiong, J.-g. Yang, and X.-h. Guo, Mat. Sci. Eng. A. 209, 287 (1996).

9. M. S. El-Eskandarany, M. Omori, M. Ishikuro, T. J. Konno, K. Takada, K. Sumiyama, T. Hirai, and K. Suzuki, Met. Mat. Trans. 27A, 4210 (1996).

10. S. Imasato, T. Kei, K. Tetsunori, and S. Shigeya, Int. J. Refract. Met. H. 13, 305 (1995).

11. H. Xie, X. Song, F. Yin, and Y. Zhang, Sci. Rep. 6, 31047 (2016).

12. R. Haubner, S. Kubelka, B. Lux, M. Griesser, and M. Grasserbauner, J. Phys. IV France. 5, 753 (1995).

13. H. C. Kim, I. J. Shon, I. K. Jung, and I. Y. Ko, Met. Mater. Int. 12, 393 (2006).

14. J. García, V. C. Ciprés, A. Blomqvist, and B. Kaplan, Int. J. Refract. Met. H. 80, 40 (2019).

15. Z. Shen, M. Johnsson, Z. Zhao, and M. Nygren, J. Am. Ceram. Soc. 85, 1921 (2002).

16. G. R. Anstis, P. Chantikul, B. R. Lawn, and D. B Marshall, J. Am. Ceram. Soc. 64, 533 (1981).

17. H.-K. Park, S.-M. Lee, H.-J. Youn, K.-S. Bang, and I.-H. Oh, Korean J. Met. Mater. 49, 40 (2011).

18. K. Jia, T. E. Fischer, and B. Gallois, Nanostruct. Mater. 10, 875 (1998).

19. B. K. Kim, G. H. Ha, and D. W. Lee, J. Mater. Process. Technol, 63, 317 (1997).

20. I. J. Shon, I. K. Jeong, I. Y. Ko, J. M. Doh, and K. D. Woo, Ceram. Int, 35, 339 (2009).

21. E. A. Almond and B. Roebuck, Mater. Sci. Eng. A. 105, 237 (1988). 